\title{
Carrion Beetles (Coleoptera, Silphidae) of Potential Forensic Importance and Their Pictorial Identification Key by User-Friendly Characters in Korea
}

Sang-Hyun Park, Tae-Young Moon

Department of Biomedical Sciences, Kosin University, Busan, Korea
Received: June 29, 2020

Revised: November 5, 2020

Accepted: November 26, 2020

\section{Correspondence to}

Tae-Young Moon

Department of Biomedical Sciences, Kosin University, 194 Wachi-ro, Yeongdo-gu, Busan 49104, Korea

Tel: +82-51-990-2156

Fax: +82-51-911-2504

E-mail: tymoon@kosin.ac.kr
To date, 26 species of silphid beetles in nine genera within two subfamilies have been recorded in Korea, among which, we examined necrophilous and necrobiont silphids with the aim of identifying candidate species that could be used as forensic indicators. We compiled a list of 15 species in seven genera and two subfamilies based on specimens obtained from 36 repeated experiments using pig cadavers and a search of previous literature: seven species in the subfamily Nicrophorinae (Nicrophorus concolor Kraatz, Nicrophorus maculifrons Kraatz, Nicrophorus quadraticollis Portevin, Nicrophorus quadripunctatus Kraatz, Nicrophorus tenuipes Lewis, Nicrophorus vespilloides Herbst, and Ptomascopus morio Kraatz), and eight species in the subfamily Silphinae (Necrodes littoralis (Linnaeus), Necrodes nigricornis Harold, Necrophila brunneicollis brunneicollis (Kraatz), Necrophila (Eusilpha) jakowlewi jakowlewi (Semenov), Oiceoptoma thoracicum (Linnaeus), Silpha (Phosphuga) atrata atrata Linnaeus, Thanatophilus rugosus (Linnaeus), and Thanatophilus sinuatus (Fabricius)). The association of these beetles with carcasses is supported by previous reports of their attraction to baited pitfall traps. The asymptote of species accumulation was determined according to the number of samplings. On the basis of the findings of this study, we believe that the 15 identified silphid species are obligate cadaver feeders and could serve as a definitive range of silphids essential for forensic investigation. However, given that criminal investigators without sufficient entomological knowledge may be unable to identify the silphid beetles obtained from corpses, we have also produced a user-friendly pictorial key that should facilitate identification of the silphids of forensic importance in Korea.

Key Words: Silphidae; Pictorial key; Forensic importance; Korea

\section{Introduction}

Medicolegal entomology is an area of forensic entomology that concerns the role of insect evidence in criminal investigations [1,2]. In routine pathological examination, it may be difficult to identify remains and accurately establish the time-since-death after more than 3 days post-mortality. In this regard, however, entomological approaches have been developed as complementary or substitute tools in forensic investigations, which are based on the observation that the insects that feed on carrion constitute a distinct faunal succession that corresponds to the progressive stages of decomposition [3]. 
Carrion beetles (Coleoptera, Silphidae) play essential roles in biological decomposition, and although primarily carrion feeders (necrophagous species), they may also act as predators by consuming other carrion inhabitants [4-7]. As such, the postmortem colonization of these beetles can provide useful information regarding the time-since-death [8-10]. For example, the findings of recent studies have indicated that Thanatophilus micans Fabricius can locate a corpse within 24 hours, and that their larvae are observed soon after death at an early stage of decomposition $[11,12]$. This implies that certain species could be pioneers in exploring corpses and thereby provide potentially useful clues for forensic investigation, similar to the behavior of blowflies that are deemed important indicators in forensic entomology [11,12].

The coleopteran family Silphidae consists of a relative small group of beetles, comprising 183 known species in 15 genera worldwide [4]. These beetles have been extensively studied in Korea, wherein 26 species in nine genera of two subfamilies have been recorded to date [13]. In general, these records have been primarily based on specimens collected from pitfall traps baited with small pieces of carrion. In contrast, the specimens examined in the present study were obtained almost entirely from the whole bodies of experimental animals. On the basis of our sampling, we attempted to familiarize with the species of potential forensic importance among the carrion beetles recorded in Korea, and for the benefit of criminal investigators keen to identify these beetles, but who lack an entomological training, we prepared a user-friendly classification key.

\section{Materials and Methods}

We initially compiled data from 64 cases reported in forensic entomology literature published in Korea, among which, carrion beetles were recorded in 32 cases. These records were subsequently combined with the data of specimens collected from 36 pig cadavers sampled at different locations in Korea:

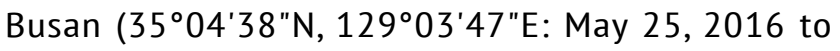

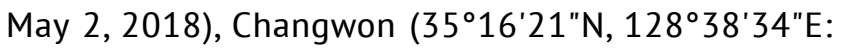
April 16 to December 5, 2018), Miryang (35 $16^{\prime} 21^{\prime \prime} \mathrm{N}$, 128³8'34"E: September 21 to December 1, 2017),
Haenam $\left(34^{\circ} 42^{\prime} 19^{\prime \prime} \mathrm{N}, 126^{\circ} 23^{\prime} 28^{\prime \prime E}\right.$ : July 11 to August 4, 2018), Mokpo (34⒌ $54^{\prime} 51^{\prime \prime} \mathrm{N}, 126^{\circ} 26^{\prime} 34^{\prime \prime} \mathrm{E}$ : April 24 to August 4, 2018), Okcheon (August 1, 2017 to July 30, 2018), Gongju (36 $28^{\prime} 17^{\prime \prime N}, 127^{\circ} 08^{\prime} 40^{\prime \prime E}$ : April 5 to July $30,2018)$, and Namyangju (37³5'48"N, $127^{\circ} 20^{\prime} 04^{\prime \prime E}$ : July 24,2017 to July 30,2018 ).

Carrion beetles were sampled by sweeping nets above and around the animal cadavers, by using baited pitfall traps, and by direct removal from the animal cadavers using forceps, in order to collect as many individuals and species as possible. Overall, we collected and examined 3,016 silphid specimens. We used the species accumulation curves to measure the saturated samplings of local species using EstimateS version 8.0 [14]. The Kruskal-Wallis test was applied to evaluate the significance of relationships between silphid richness in three different seasons (spring, summer, and autumn) and in different geographical locations. In addition, we performed cluster analysis using the SIMPROF test, based on Bray-Curtis similarity, to determine the dissimilarity in carrion beetle species composition with respect to seasonal and geographical variation.

Identification of collected specimens was carried out under an Olympus SZ61 stereomicroscope (Tokyo, Japan) using taxonomic keys and characters proposed by Cho [13] and Dekeursschieter et al. [15].

\section{Results}

\section{A list of Korean Silphidae of potential forensic importance}

To date, 26 species in the coleopteran family Silphidae have been recorded in Korea, among which, 13 species are from each of the two subfamilies Nicrophorinae and Silphinae. Of these species, we obtained 15 from animal cadavers in the present study: seven species in Nicrophorinae (Nicrophorus concolor Kraatz, Nicrophorus maculifrons Kraatz, Nicrophorus quadraticollis Portevin, Nicrophorus quadripunctatus Kraatz, Nicrophorus tenuipes Lewis, Nicrophorus vespilloides Herbst, and Ptomascopus morio Kraatz), and eight species in Silphinae (Necrodes littoralis (Linnaeus), Necrodes nigricornis Harold, Necrophila brunneicollis brunneicollis (Kraatz), Necrophila 
(Eusilpha) jakowlewi jakowlewi (Semenov), Oiceoptoma thoracicum (Linnaeus), Silpha (Phosphuga) atrata atrata Linnaeus, Thanatophilus rugosus (Linnaeus), and Thanatophilus sinuatus (Fabricius)), all of which are either obligate carrion feeders or predators (Table 1) [16-32]. Three of these species have previously been reported from animal carcasses, namely, $N$. vespilloides and S. (Phosphuga) atrata atrata recorded from rabbits in Busan [22,25] and O. thoracicum from pigs in Busan and Asan [24,29,32]. N. quadraticollis and N. tenuipes found in Okcheon are newly identified from pigs.

\section{Species richness and composition}

We found that the species accumulation curve generated in this study approached the asymptote (Fig. 1), thereby indicating that the sampling of carrion beetle had almost reached saturation for the species of cadaver fauna. We also established that the species richness of carrion beetles did not differ significantly among the three seasons assessed (Kruskal-Wallis test, $\mathrm{P}>0.05$ ) or among the regions surveyed (Kruskal-Wallis test, $\mathrm{P}>0.05$ ). Consistently, SIMPROF analysis indicated there were no significant differences among regions with respect to the composition of carrion beetle species (SIMPROF, $\mathrm{P}>0.05$ ).

Furthermore, we found that $N$. (Calosilpha) brunneicollis brunneicollis, Ne. littoralis, and Ne. nigricornis were more frequently attracted $(>40 \%)$ to the animal cadavers than other species (Fig. 2), whereas

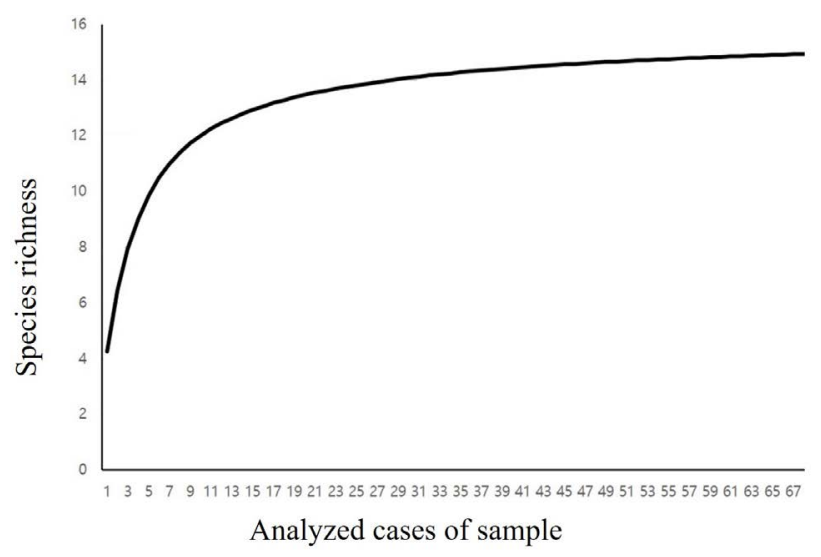

Fig. 1. Species accumulation curve for carrion beetles on animal cadavers in Korea.

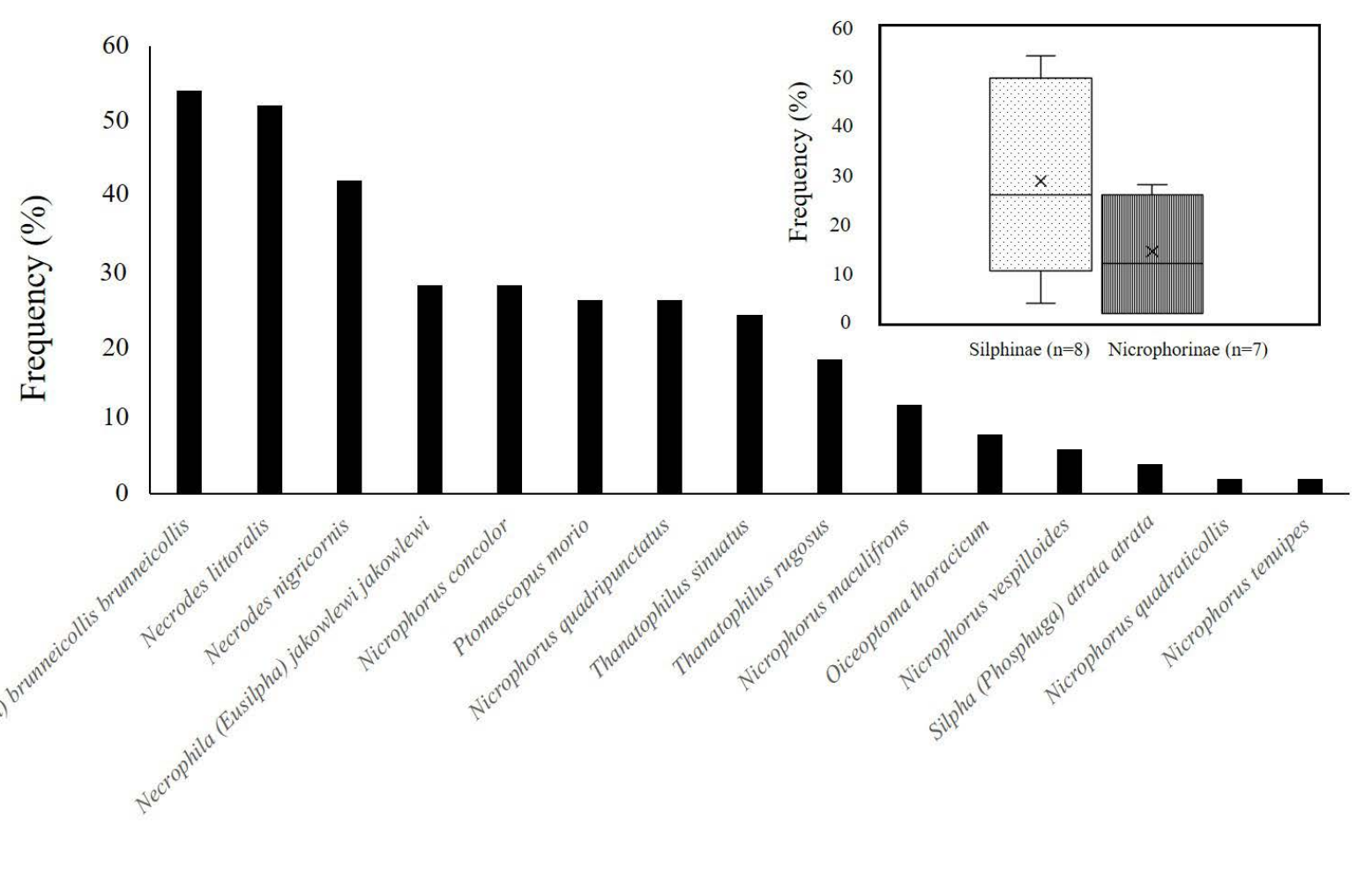

Fig. 2. The case frequencies of 15 silphid species sampled in 68 cases and the comparison between Silphinae and Nicrophorinae in a box plot. 
Table 1. List of the Korean species of carrion beetles

\begin{tabular}{|c|c|c|c|c|c|c|c|c|c|}
\hline \multirow[t]{2}{*}{ Subfamily } & \multirow[t]{2}{*}{ Species } & \multirow{2}{*}{$\begin{array}{l}\text { Body } \\
\text { size } \\
(\mathrm{mm})\end{array}$} & \multirow[t]{2}{*}{ Feeding habit } & \multirow[t]{2}{*}{ Distribution $^{a}$} & \multicolumn{4}{|c|}{$\begin{array}{c}\text { Animal cadaver in } \\
\text { experiment }\end{array}$} & \multirow[t]{2}{*}{ Reference } \\
\hline & & & & & A & B & C & D & \\
\hline \multirow[t]{13}{*}{ Nicrophorinae } & Nicrophorus basalis & $18-22$ & - & HN, HWN, PB, PN & - & - & - & - & \\
\hline & $\begin{array}{l}\text { Nicrophorus } \\
\text { concolor }^{b)}\end{array}$ & $30-40$ & - & $\begin{array}{l}\mathrm{CB}, \mathrm{CN}, \mathrm{GB}, \mathrm{GG}, \mathrm{GN}, \mathrm{GW}, \mathrm{HWN}, \\
\mathrm{JB}, \mathrm{JN}, \mathrm{PB}\end{array}$ & - & + & - & - & [16] \\
\hline & Nicrophorus dauricus & $14-24$ & - & $\mathrm{CN}, \mathrm{GB}, \mathrm{GG}, \mathrm{HN}, \mathrm{PB}$ & - & - & - & - & \\
\hline & $\begin{array}{l}\text { Nicrophorus } \\
\text { investigator }\end{array}$ & $14-23$ & $\begin{array}{l}\text { Necrophagous or } \\
\text { predaceous }\end{array}$ & $\mathrm{CB}, \mathrm{GB}, \mathrm{GN}, \mathrm{GW}, \mathrm{HWB}, \mathrm{JB}, \mathrm{PB}$ & - & - & - & - & {$[15,17]$} \\
\hline & Nicrophorus japonicus & $22-32$ & - & $\mathrm{CB}, \mathrm{CN}, \mathrm{GG}, \mathrm{GW}, \mathrm{JJ}, \mathrm{PB}$ & - & - & - & - & - \\
\hline & $\begin{array}{l}\text { Nicrophorus } \\
\text { maculifrons }\end{array}$ & $15-25$ & Necrophagous & $\begin{array}{l}\mathrm{CB}, \mathrm{CN}, \mathrm{GB}, \mathrm{GG}, \mathrm{GN}, \mathrm{GW}, \mathrm{JB}, \mathrm{J}, \\
\mathrm{JN}\end{array}$ & - & - & + & - & {$[18-20]$} \\
\hline & $\begin{array}{l}\text { Nicrophorus } \\
\text { quadraticollis }\end{array}$ & $13-18$ & - & $\mathrm{CB}, \mathrm{CN}, \mathrm{GB}, \mathrm{GW}$ & - & - & - & - & - \\
\hline & $\begin{array}{l}\text { Nicrophorus } \\
\text { quadripunctatus }\end{array}$ & $14-21$ & Necrophagous & $\begin{array}{l}\mathrm{CB}, \mathrm{CN}, \mathrm{GB}, \mathrm{GG}, \mathrm{GN}, \mathrm{GW}, \mathrm{JB}, \mathrm{J}, \\
\mathrm{JN}, \mathrm{PB}\end{array}$ & + & + & + & - & {$[18,21-24]$} \\
\hline & $\begin{array}{l}\text { Nicrophorus } \\
\text { tenuipes }\end{array}$ & $18-20$ & Necrophagous & $\mathrm{CN}, \mathrm{GB}, \mathrm{GG}, \mathrm{GW}, \mathrm{JG}, \mathrm{PB}, \mathrm{YG}$ & - & - & - & - & {$[18]$} \\
\hline & $\begin{array}{l}\text { Nicrophorus } \\
\text { ussuriensis }\end{array}$ & $16-18$ & - & GW & - & - & - & - & - \\
\hline & $\begin{array}{l}\text { Nicrophorus } \\
\text { vespilloides }^{\text {b) }}\end{array}$ & $10-20$ & $\begin{array}{l}\text { Necrophagous or } \\
\text { predaceous }\end{array}$ & $\mathrm{GB}, \mathrm{GG}, \mathrm{GN}, \mathrm{HB}, \mathrm{PB}$ & - & + & - & - & {$[15-17]$} \\
\hline & Ptomascopus morio ${ }^{b}$ & $14-17$ & Parasitic & $\begin{array}{l}\mathrm{CB}, \mathrm{CN}, \mathrm{GB}, \mathrm{GG}, \mathrm{GN}, \mathrm{GW}, \mathrm{HWN}, \\
\mathrm{JB}, \mathrm{JJ}, \mathrm{JN}, \mathrm{PB}\end{array}$ & + & + & - & - & {$[19,24-26]$} \\
\hline & $\begin{array}{l}\text { Ptomascopus } \\
\text { plagiatus }\end{array}$ & $13-16$ & - & GG, GW, HWB & - & - & - & - & - \\
\hline \multirow[t]{13}{*}{ Silphinae } & Aclypea daurica & $11-16$ & Phytophagous & GB, GG, GW, HB, JB, PB, YG & - & - & - & - & [13] \\
\hline & $\begin{array}{l}\text { Dendroxena } \\
\text { sexcarinata }\end{array}$ & $12-16$ & Predaceous & $\mathrm{CB}, \mathrm{CN}, \mathrm{GB}, \mathrm{GG}, \mathrm{GW}, \mathrm{HB}, \mathrm{JN}, \mathrm{PB}$ & - & - & - & - & {$[27]$} \\
\hline & Necrodes littoralis ${ }^{\mathrm{b})}$ & $15-28$ & $\begin{array}{l}\text { Necrophagous or } \\
\text { predaceous }\end{array}$ & $\begin{array}{l}\mathrm{CB}, \mathrm{CN}, \mathrm{GB}, \mathrm{GG}, \mathrm{GN}, \mathrm{GW}, \mathrm{JB}, \mathrm{JJ}, \\
\mathrm{JN}, \mathrm{PB}, \mathrm{YG}\end{array}$ & - & + & + & + & {$[19,24,28-30]$} \\
\hline & Necrodes nigricornis ${ }^{\mathrm{b})}$ & $15-20$ & - & $\mathrm{CB}, \mathrm{CN}, \mathrm{GG}, \mathrm{GN}, \mathrm{GW}, \mathrm{JB}, \mathrm{JJ}, \mathrm{JN}$ & - & - & + & - & {$[19,24,25,28,30]$} \\
\hline & $\begin{array}{l}\text { Necrophila } \\
\text { brunneicollis } \\
\text { brunneicollis }^{\text {b) }}\end{array}$ & $18-25$ & Necrophagous & $\begin{array}{l}\mathrm{CB}, \mathrm{CN}, \mathrm{GB}, \mathrm{GG}, \mathrm{GN}, \mathrm{GW}, \mathrm{HB}, \mathrm{HN}, \\
\mathrm{JB}, \mathrm{JJ}, \mathrm{JN}, \mathrm{PB}\end{array}$ & - & + & + & - & {$[18-20,30,31]$} \\
\hline & $\begin{array}{l}\text { Necrophila jakowlewi } \\
\text { jakowlewi }^{\text {b) }}\end{array}$ & $11-23$ & Predaceous & $\begin{array}{l}\mathrm{CB}, \mathrm{CN}, \mathrm{GB}, \mathrm{GG}, \mathrm{GN}, \mathrm{GW}, \mathrm{JB}, \mathrm{JJ}, \\
\mathrm{JN}\end{array}$ & + & - & + & - & {$[18,19,24,32]$} \\
\hline & $\begin{array}{l}\text { Oiceoptoma } \\
\text { subrufum }\end{array}$ & $15-17$ & Necrophagous & $\mathrm{GB}, \mathrm{GW}, \mathrm{JB}, \mathrm{PB}$ & - & - & - & - & [18] \\
\hline & $\begin{array}{l}\text { Oiceoptoma } \\
\text { thoracicum }^{\text {b) }}\end{array}$ & $15-17$ & $\begin{array}{l}\text { Necrophagous or } \\
\text { predaceous }\end{array}$ & $\begin{array}{l}C B, C N, G B, G N, G W, H N, J J, J N, \\
Y G\end{array}$ & - & - & + & + & {$[15,24,29,32]$} \\
\hline & Silpha atrata atrata ${ }^{\mathrm{b})}$ & $14-18$ & Predaceous & $\mathrm{GN}, \mathrm{GW}, \mathrm{HB}, \mathrm{PB}$ & + & + & - & - & {$[15,18,21,23]$} \\
\hline & Silpha koreana & $16-17$ & - & GW & - & - & - & - & - \\
\hline & Silpha perforata & $15-20$ & Predaceous & $\mathrm{GB}, \mathrm{GW}, \mathrm{HB}, \mathrm{HN}, \mathrm{HWB}, \mathrm{JB}, \mathrm{JJ}, \mathrm{YG}$ & - & - & - & - & [18] \\
\hline & $\begin{array}{l}\text { Thanatophilus } \\
\text { rugosus }^{\text {b) }}\end{array}$ & $8-12$ & $\begin{array}{l}\text { Necrophagous or } \\
\text { predaceous }\end{array}$ & $\mathrm{CN}, \mathrm{GB}, \mathrm{GG}, \mathrm{GN}, \mathrm{GW}, \mathrm{JB}, \mathrm{JJ}, \mathrm{JN}$ & + & - & + & - & {$[15,17,19,21,28]$} \\
\hline & $\begin{array}{l}\text { Thanatophilus } \\
\text { sinuatus }\end{array}$ & $9-12$ & $\begin{array}{l}\text { Necrophagous or } \\
\text { predaceous }\end{array}$ & $\begin{array}{l}\mathrm{CB}, \mathrm{CN}, \mathrm{GB}, \mathrm{GG}, \mathrm{GN}, \mathrm{GW}, \mathrm{JB}, \mathrm{JN} \text {, } \\
\mathrm{JJ}\end{array}$ & + & - & + & - & {$[15,17,19,30]$} \\
\hline
\end{tabular}

Animal cadaver in experiment: $A$, bird; $B$, rabbit; $C$, pig; $D$, piece of pig.

${ }^{a}$ Distribution: $\mathrm{CB}$, Chungcheongbuk-do; CN, Chungcheongnam-do; GB, Gyeongsangbuk-do; GG, Gyeonggi-do; GN, Gyeongsangnam-do; GW, Gangwon-do; HB, Hamgyeongbuk-do; HN, Hamgyeongnam-do; HWB, Hwanghaebuk-do; HWN, Hwanghaenam-do; JB, Jeollabuk-do; JG,

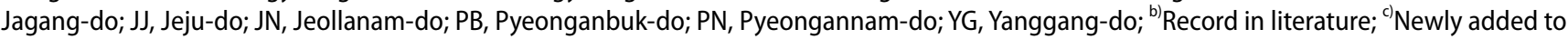
cadaver fauna. 
N. quadraticollis and N. tenuipes were observed only once on a pig cadaver at Okcheon.

\section{A key to the Korean Silphidae of potential forensic importance}

With the aim of assisting criminal and forensic investigators who wish to perform the rapid identification of cadaver-associated beetles and thereby potentially discover clues of forensic relevance, we prepared a relatively simple identification key to the important Korean fauna (Fig. 3). The concept and diagnostic combination of taxonomic characters were based on previous keys proposed by Cho [13] and Dekeirsschieter et al. [15], the user-friendliness of which was evaluated by conducting trail sessions with different groups of taxonomic novices.

\section{Discussion}

Although generally associated with decomposition, not all carrion beetles are considered to be of forensic

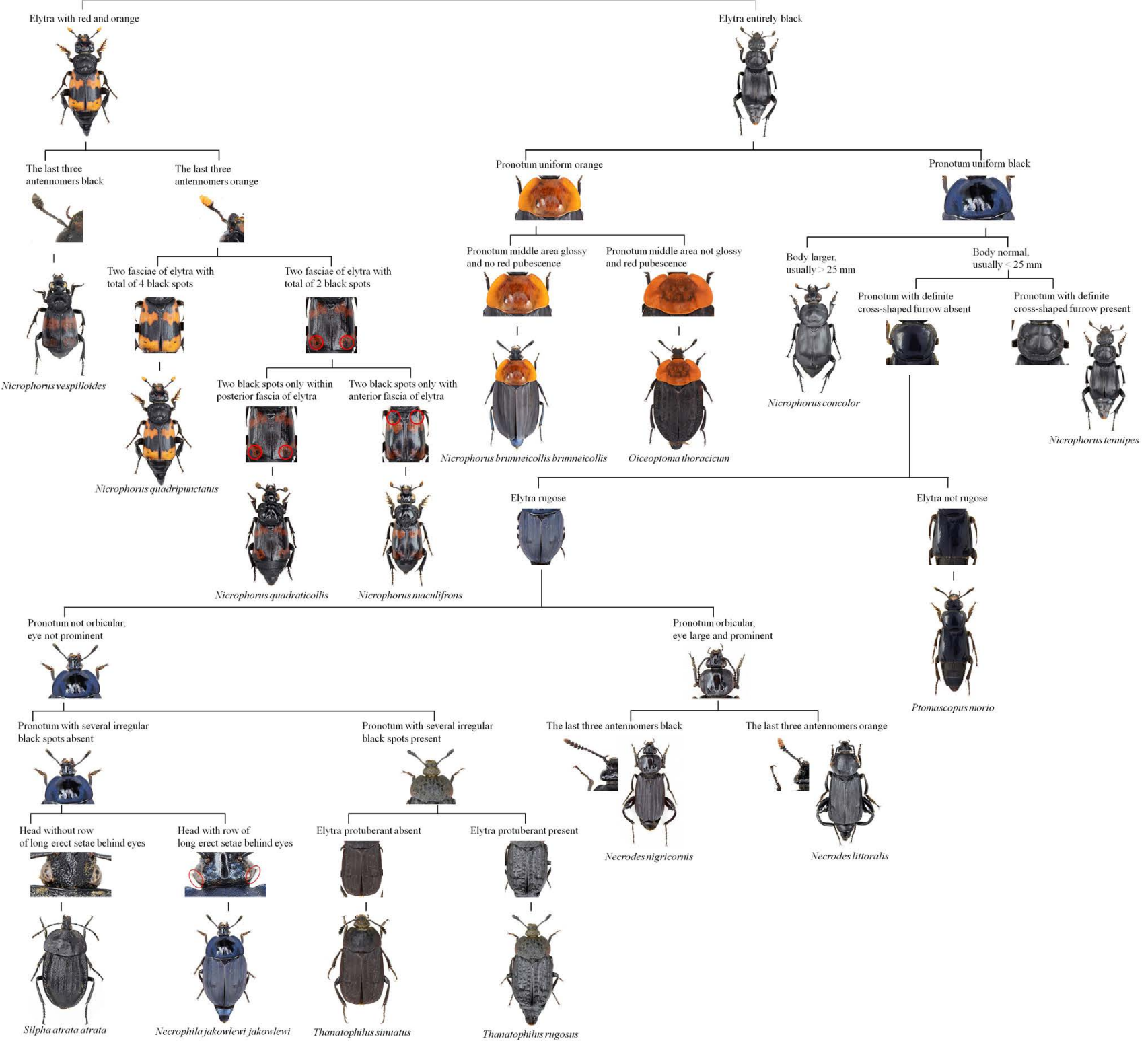

Fig. 3. The pictorial key to the Korean carrion beetles of potential forensic importance using external morphological characters. 
relevance, and the findings of the present study and observations reported in the literature would appear to indicate that only 15 of the 26 species recorded in Korea are typically associated with cadavers.

On the basis of our observations indicating that species in the subfamily Silphinae are more frequently attracted to animal cadavers than are those in the subfamily Nicrophorinae (as shown in Fig. 2), we believe that silphinid species may be worth studying with regards to their potential utility as forensic bioindicators $[10,33]$. Indeed, these beetles typically deposit and abandon their eggs in or on soil in the vicinity of larger carcasses (>300 g), whereas Nicrophorus species in the Nicrophorinae tend to bury eggs within subterranean nests near smaller carcasses (generally $<100 \mathrm{~g}$ ), in which they guard their egg and exhibit biparental care throughout larval development [4]. P. morio is also known to be a brood parasite of Nicrophorus beetles [26].

Carrion beetles generally have a longer life cycle than dipteran species [11,12], and can also colonize corpses during the latter stages of decay when maggots have departed to pupate $[12,34,35]$. Therefore, the use of carrion beetles as bioindicators may be of potentially greater value from the perspective of forensic practice. However, given the general lack of interest in the Silphidae in forensic science, there has to date been no user-friendly key available for the purpose of identifying carrion beetles that occur on cadavers. To rectify this deficiency, we sought to prepare a reliable pictorial key that can be used to identify those species found on human and animal corpses.

We believe that this key will prove useful to those inexperienced in Silphidae taxonomy, as the characters upon which the key is based are generally external morphological features that are readily visible to the naked eye. Although relatively simple, we anticipate that this type of pictorial key would assist criminal investigators as taxonomic novices, thereby highlighting its importance [23]. This is particularly so, given that there are generally few local experts available to advise on matters relating to entomological identification, and that a correct identification of species and a reasonable understanding of their behavior is crucial for successful forensic interpretation.
ORCID: Sang-Hyun Park: https://orcid.org/0000-00031096-9272; Tae-Young Moon: https://orcid.org/00000003-2123-9099

Conflicts of Interest

No potential conflict of interest relevant to this article was reported.

\section{Acknowledgments}

We would like to appreciate Ji-Whan LEE and BongWhan JI for field works, Da-Hyun WOO (Kosin University) for database work, and Dr. Min Hyeuk LEE (Korea National Park Service) for taking the photos of Silphidae, and. This research was supported by the Projects for Research and Development of Police and Technology under the Center for Research and Development of Police Science and Technology and the Korean National Police Agency (PA-G000001).

\section{References}

1. Hall RD. Medicocriminal entomology. In: Catts EP, Haskell NH, eds. Entomology and death: a procedural guide. Clemson, SC: Joyce's Print Shop; 1990. p. 1-8.

2. Hall RD. Perceptions and status of forensic entomology. In: Byrd $\mathrm{JH}$, Castner JL, eds. Forensic entomology: the utility of arthropods in legal investigations. 2nd ed. Boca Raton, FL: CRC Press; 2000. p. 1-15.

3. Sert 0, Kabalak M, Sabanoglu B. Determination of forensically important Coleoptera and Calliphoridae (Diptera) species on decomposing dog (Canis lupus familiaris L.) carcass at Ankara province. Hacettepe J Biol Chem 2012;40:99-103.

4. Sikes DS. Carrion beetles (Coleoptera: Silphidae). In: Capinera JL, ed. Encyclopedia of entomology. Dordrecht: Springer; 2008. p. 749-57.

5. Ratcliffe BC. Bulletin of the University of Nebraska State Museum, Vol. 13. The carrion beetles (Coleoptera: Silphidae) of Nebraska. Lincoln, NE: University of Nebraska State Museum; 1996.

6. Hastir P, Gaspar C. Diagnose d'une famille de fossoyeurs: les Silphidae [Diagnosis of a family of gravediggers: the Silphidae]. Notes Fauniques Gembloux 2001;44:13-25.

7. Sikes DS. Silphidae Latreille, 1807. In: Kristensen NP, Beutel RG, eds. Handbook of zoology. Vol. 4. Arthropoda: Insecta. Berlin: Waler de Gruyter; 2005. p. 288-96.

8. Smith KG. A manual of forensic entomology. London: Trustees of the British Museum; 1986.

9. Haskell NH, Hall R, Cervenka VJ, et al. On the body: insects' life stage presence and their postmortem artifacts. In: Haglund WD, Sorg MH, eds. Forensic taphonomy: the postmortem fate of human remains. Boca Raton, FL: CRC Press; 1997. p. 415-45. 
10. Watson EJ, Carton CE. Succession of forensically significant carrion beetle larvae on large carcasses (Coleoptera: Silphidae). Southeast Nat 2005;4:335-46.

11. Midgley JM, Villet MH. Development of Thanatophilus micans (Fabricius 1794) (Coleoptera: Silphidae) at constant temperatures. Int J Legal Med 2009;123:285-92.

12. Midgley JM, Richards CS, Villet MH. The utility of Coleoptera in forensic investigations. In: Amendt J, Goff ML, Campobasso CP, et al., eds. Current concepts in forensic entomology. Dordrecht: Springer; 2010. p. 57-68.

13. Cho YB. Insect fauna of Korea. Vol. 12, No. 14. Carrion beetle: Arthropoda: Insecta: Coleoptera: Silphidae. Incheon: National Institute of Biological Resources; 2014.

14. Colwell RK. Estimates: statistical estimation of species richness and shared species from sample. Version 8.0 user's guide and application [Internet]. The Author; 2007 [cited 2020 0ct 10]. Available from: http://viceroy.eeb.uconn.ed/EstimateS.

15. Dekeirsschieter J, Verheggen F, Lognay G, et al. Large carrion beetles (Coleoptera, Silphidae) in Western Europe: a review. Biotechnol Agron Soc Environ 2011;15:435-47.

16. Moon TY. Systematics and forensic ecology of saprophagous insects on fishes and birds by opportunistic samplings in Pusan. Entomol Res Bull 1996;22:67-72.

17. Kocarek P. Diurnal activity rhythms and niche differentiation in a carrion beetle assemblage (Coleoptera: Silphidae) in Opava, the Czech Republic. Biol Rhythm Res 2001;32:431-8.

18. Ikeda H, Kagaya T, Kubota K, et al. Evolutionary relationships among food habit, loss of flight, and reproductive traits: lifehistory evolution in the Silphinae (Coleoptera: Silphidae). Evolution 2008;62:2065-79.

19. Park SJ, Byun HW, Hur J, et al. Investigation and application of forensic insects of the Korean peninsula. Incheon: National Institute of Biological Resources; 2011.

20. Jung JB, Yoon MH. A forensic entomological study using pig carrions in different seasons and the exposed extent. Korean Police Stud Rev 2013;12:335-54.

21. Moon TY. Diversity and succession of saprophagous entomofauna on exposed rabbit carrions in Pusan. Kosin J Health Sci 1996;6:53-64.

22. Ohkawara K, Suzuki S, Katakura H. Competitive interaction and niche differentiation among burying beetles (Silphidae, Nicrophorus) in northern Japan. Entomol Sci 1998;1:551-9.

23. Tilling S. Keys to biological identification: their role and construction.J Biol Educ 1984;18:293-304.

24. Jung JB, Park SS, Song TH, et al. A study on decomposition and insect fauna of carrions exposed to the sun and shade. Korean Police Stud Rev 2015;14:539-56.

25. Moon TY, Kajii E. Forensic implication of predominant insects on rabbit carrions at the islet Youngdo in Pusan. Entomol Res Bull 1997;23:29-36.

26. Trumbo ST, Kon M, Sikes D. The reproductive biology of Ptomascopus morio, a brood parasite of Nicrophorus. J Zool 2001;255:543-60.

27. Sugiura S, Yamazaki K. Outbreak of Ivela auripes (Lepidoptera, Lymantridae) and its arboreal predator Dendroxena sexcarinata (Coleoptera, Silphidae). Lepidoptera Sci 2007;58:40-2.

28. Hyun CH, Kim BS, Shin SE, et al. Postmortem of interval (PMI) measurement through observation on decaying pig carcasses. Korean J Sci Crim Investig 2011;5:344-51.

29. Jung JB. A forensic medical and entomological study using pig carrions [thesis]. Busan: Kyungsung University Press; 2014.

30. Jung JB, Yoon MH. Decomposition pattern and entomofauna in the pig carcasses in different conditions. J Sci Crim Investig 2016;10:187-94.

31. Jung JB, Yoon MH. A study on the arthropod succession in exposed pig carrion.J Life Sci 2008;18:1400-9.

32. Jung JB, Yoon MH. Decomposition rates and the entomofauna in pig legs in a plastic and a resin bag, and buried under the ground. Korean Police Stud Rev 2014;13:299-322.

33. Matuszewski S, Bejerlein D, Konwerski S, et al. Insect succession and carrion decomposition in selected forests of Central Europe. Part 2: Composition and residency patterns of carrion fauna. Forensic Sci Int 2010;195:42-51.

34. Kocarek P. Decomposition and Coleoptera succession on exposed carrion of small mammal in Opava, the Czech Republic. Eur J Soil Biol 2003;39:31-45.

35. Matuszewski S, Bejerlein D, Konwerski S, et al. An initial study of insect succession and carrion decomposition in various forest habitats of Central Europe. Forensic Sci Int 2008;180:61-9. 